Sipos Ciprian 1

\title{
A Comparative Analysis of Property Taxation Within EUROPEAN UNION
}

\section{Abstract:}

The correct settlement of a property taxation system is a topic of interest at the moment, which draws attention in economic or academic debates. One of the most convenient alternatives and easier to implement in order to raise revenues to the state budget is the taxation of property. The comparative analysis of property tax systems in the European Union reveals the need to develop and modernize the property tax system in the new member countries. The tax paid by taxpayers who own property is considered the tax with the fewest negative effects on economic growth, given the immobility of the subject of taxation. This reduces the behavioural effects of this type of tax and minimizes economic distortions. For this reason, is considered necessary to be presented the recent European perspective regarding the taxation of property, be it buildings for housing or special purpose, owned by individuals or corporate. In these conditions, the paper aims to analyze the correlation between the purchasing power of citizens of EU28 countries and the level of property taxes and to perform a grouping of European Union countries according to these indicators. The findings can help governments of the new member countries of European Union to develop a property tax system that would lead to the economic development.

\section{Keywords:}

property taxation system, purchasing power, EU countries

\section{Author's data:}

1 Sipos Ciprian, Associate Professor, Ph.D., West University of Timisoara, Faculty of Economics and Business Administration, Pestalozzi 16, Timisoara, Romania, ciprian.sipos@e-uut.ro 


\section{Introduction}

As a consequence of the global crisis that affected the most of the European countries, the governments are looking the best ways to get more money to the budget. A proper settlement of property taxes is one of the best solutions to this important problem. Therefore, many European countries have made significant changes in their property taxes in the last two years. For these reasons, the paper aims to study, in comparative terms, the possibilities of modernizing and harmonizing the system of property taxes in Europe. Thus, the paper analyzes the measures taken in many European countries mainly in 2013 in the field of property taxation and particularly regarding housing properties which are trying to correlate the taxation system to real needs of the present economy.

Compared to other categories of taxes, the property taxes do not seem to distort the economic decisions to employ, to invest in human capital or to produce and innovate. Property taxation is the most convenient and easy to implement option in the terms of raising the amount of taxes paid to the state budget [7]. However, changing the property taxes is a practical measure for governments from a number of reasons.

Firstly, because a building or a land has a visible and immobile character, it is more difficult for taxpayers to evade this tax. Meanwhile, the amount of the taxed base is relatively constant, which can be particularly attractive at a time when the values which are subject to impose for other taxes become increasingly mobile, especially due to the globalization [2]. For example, the income tax reduces subsequent return on investment, reduce incentives to invest and innovate, while personal income taxes can influence hiring decisions. Comparing to these, the consumption taxes and the taxes on the immovable property are less harmful to the economic efficiency and growth [6]. The taxes on capital transactions cincluding here the taxes on the transfer of property] may have a dissuasive effect on transactions which effectively allocate resources in the economy [10].

A proper tax policy aids the recovery from the economic crisis and helps to long-run growth [3]. In these conditions, taxes on property, with a regular update of the methodology tax, may increase the progressivity of the tax system (for example, exemption from taxation of low-value properties or of people with low incomes]. Permanent correlation of property taxation with market value would increase or decrease the size of imposing along with the general trend of the economy without direct intervention of the state in managing this tax [12].

Starting from these assessments, the paper main objectives are to present the recent European perspective regarding the significant changes in the taxation of property and to analyze the correlation between the purchasing power of citizens of EU28 countries, given by the GDP/capita, and the level of property taxes. Then is performed a grouping of European Union countries according to these two indicators in order to study the level of homogeneity within the EU28 in terms of property taxes level and the living standards of citizens of the European countries. The results of this research wants to argue that governments have to take measures in order to optimize and harmonize the system of property taxation in the European Union.

\section{The European perspective regarding the taxation of property}

During the last two years, almost half of the European Union countries made changes to property taxation system. Therefore, it seems that exist the desire of authorities to do the property taxation system more effectively and to increase 
revenue to the state budget in a way more favourable for taxpayers [4]. The annual property taxation may be one correct way to increase the government revenue, even though this will be a in a less extent than other taxes. However, it is acceptable to increase the property taxes only if the amount of revenues to the state budget of other types of taxes is maintained at the same level [8].

Although is very accredited the idea that there are many reasons for the governments to rely more heavily on property taxes, these taxes are underused in practice in many countries of European Union [1]. In some cases, the budget revenues raised from property taxes are much lower than the income accruing from other types of taxes as percents of GDP. At the same time, there are other forms of property taxes, the most common being the taxes on transfer of property, in other words when the ownership of real estate is transferred through sale. These taxes are high in Belgium, Italy, Luxembourg, Malta and France. One of the measures that can be taken by governments is to increase the rental income taxation. However, this will lead to increased rents, which can be reflected in higher prices for certain services [11]. Especially in big European cities, the rent represents a significant percentage of the cost of service providers, so they may be strongly affected by this measure.

Often, in the EU countries, taxation includes taxincentives for indebting to buy a property, in the sense of a deduction of mortgage interest expense from income tax calculation. This seems to have generated in the EU property market an instability and a debt crisis, so the tax Iegislation in several states in 2013aimed at reducing mortgage interest deductibility. For example spain (since 2013) and Belgium (since 2014) have opted for a total elimination of the deductibility of interest in these cases, while the Netherlands, Finland and Estonia have taken measures to gradually reduce the amount of deductibles. As we have said, about half of the EU member states have amended in the last period the legislation on annual property taxes, be it buildings or land. An example of changing the property taxation system is Ireland, where a new local property tax was introduced in July 2013 [0.18\% rate for residential properties with a value under EUR 1 million]. Great Britain adopted a new annual tax for the taxable value of properties over $£ 2$ million held by legal entities. Lithuania and Latvia have broadened the tax base on property and new rates will be determined by local authorities.

In some new EU countries, the property taxation became progressive to attenuate the potential social impact. Slovenia has introduced an increased tax for properties worth over 500,000 Euros [0.5\%) and over 2 million $[1 \%$ ]. Romania has introduced in 2013 a new tax on special construction from sectors as energy, telecommunications, utilities, transport and infra-structure, which has generated many discussions on the impact of the new taxes in the price of energy and fuel. In most of the countries in Eastern Europe, the ratio between residential prices and population incomes is much higher than in developed countries [5]. One of the important causes that led to this situation is the policy regarding the property taxes. Thus, the reduced rates of property taxation led to relative affordable ownership, while low degree of taxation of the rental market has generated significant additional revenues. All of these contributed to the development of the housing bubble before the crisis and the development of prices without correlation with the purchasing power of the population [9].

In all former communist countries, especially on the individuals' taxation sector, property tax is extremely low, but at least so far, no government had the courage to significantly increase this tax. 
Beyond that affect budget revenues, low taxes paid by owners greatly contribute to maintaining high prices on real estate market [5]. It is true that many find it difficult to pay a high tax of the home, but for the really poor people can apply various reductions or exemptions to make taxes more supportable. However, in the developed countries, very poor people cannot afford to be owners of a house (situation that is quite common in Eastern European countries].

The poor tax administration is the most important constraint on the implementation of property taxin developing countries. There is a well known critical saying that governments in developing countries are practically unable to administer

a property tax that works very well in the developed countries [4]. Usually, in Eastern European countries, property tax varies much more than in developed countries regarding taxation base, setting the tax rate, the registration, classification and valuation of property. These fluctuations give a great inconsistency to tax policies and transmit to the citizen a lack of transparency and credibility. In addition to these, in most European countries, the general settlement of property taxation system is regulated by the central authorities, but the exact property tax to pay is determined by the local authorities. This leads to the need to harmonize central and local legislation. In most cases, this is difficult to achieve and leads to a lack of homogeneity of the property taxation system within the country, especially in the larger countries. These gaps in homogeneity are transmitted in stronger ways at the level of the European Union.

As can be seen from this succinct presentation of the European perspective regarding the taxation of property, the trend for EU member states is to increase the state budget revenues from annual property tax. Given the still difficult situation of the housing market, but also due to increasingly heavy lending conditions, increasing annual tax on property appears to be more effective than raising taxes on real estate transactions. This measure seems to be most appropriate if is desired a tax revenue growth from this area.

\section{Positioning of EU countries by GDP/capita and Taxes on property}

Based on data provided by the "Taxation Trends in the European Union" - 2013 Edition published by Eurostat[13] are grouped the Eu27 countries by GDP/capita and Taxes on property as percents of GDP. To have the complete study, for EU28, are added the data for Croatia from other statistics of Eurostat [14]. The data refers to year 2011, which are the most recent available for taxes on property.

The econometric research method used in the paper consists in calculating and interpreting the linear correlation coefficients and in analyzing the main parameters of the simple linear regression. The reason of using these methods is that the classical linear regression model is one of the most versatile and commonly used econometric techniques in economic analysis. The main purpose of the use of the regression model is to obtain the parameters corresponding to a set of variables, by analyzing the dependence between the variables when the series of data are recorded for a period or a moment of time. The main weakness of the regression method used is that in some cases it is found that the linear relationship appears to be inadequate to completely describe the dependence between variables or the scales used are not the most appropriate.

Thus, the linear correlation coefficient calculated for the EU28 is only 0.311 which shows that there is not a very strong correlation between GDP/capita and Taxes on property. Similar values of correlation 
coefficients are obtained using indicators as Purchasing Power standard per inhabitant or
GDP/capita calculated as percentage of EU28 total, as is shown in the following table:

\begin{tabular}{|l|l|}
\hline Variables & Taxes on property as \% of GDP \\
\hline GDP/capita [Euro/inhabitant] & 0.311660905 \\
\hline Purchasing Power Standard per inhabitant & 0.233691806 \\
\hline GDP/capita (as percentage of EU28 totall & 0.311772892 \\
\hline
\end{tabular}

\section{Table 1.: The values of the linear correlation coefficients}

The detailed statistics of correlation between GDP/capita and Taxes on property is given in the following table:

\begin{tabular}{|c|c|c|c|c|}
\hline \multicolumn{5}{|c|}{ Regression statistics } \\
\hline Multiple R & 0.311660905 & \multicolumn{2}{|c|}{ Standard Error } & 0.92391708 \\
\hline R Square & 0.09713252 & \multicolumn{2}{|c|}{ Observations } & 28 \\
\hline Adjusted R Square & 0.062406847 & & & \\
\hline ANOVA & df & SS & MS & $\mathrm{F}$ \\
\hline Regression & 1 & 2.387701 & 2.38770 & 2.797138 \\
\hline Residual & 26 & 22.19419 & 0.85362 & Significance F \\
\hline \multirow[t]{2}{*}{ Total } & 27 & 24.58189 & & 0.106425601 \\
\hline & Coefficients & Std. Error & t stat & P-value \\
\hline Intercept & 0.851888958 & 0.320342 & 2.65930 & 0.013226 \\
\hline GDP/capita & $1.8769 \mathrm{E}-05$ & 1.124E-05 & 1.67246 & 0.1064256 \\
\hline
\end{tabular}

\section{Table 2.: The detailed statistics of linear regression}

The Line Fit Plot figure shows the positioning of points regarding the correlation between GDP/capita and Taxes on property:

\section{Line Fit Plot}

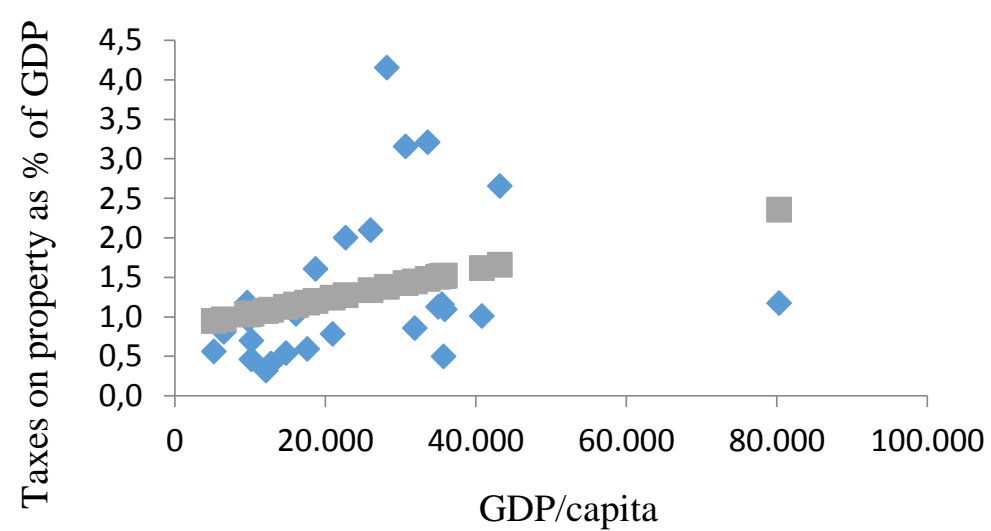

\section{Figure 1.: The Line Fit Plot of regression function}

International Journal - VALLIS AUREA • Volume 1 - Number 1 - Croatia, June 2015 UDK 336.226.2-042.2:061.1EU; DOI 10.2507.IJVA.1.1.6.6 
It can be seen from Table 2 that the regression between GDP/capita and Taxes on property in EU28 is not very significant. The values of Multiple $R, R$ Square and Adjusted R Square are small. Regarding the Fisher test, the calculated value $\mathrm{F}$ is not very high while significance $F$ is large. Also, $t$ stat values of Student test are not very high and probabilities P-values, especially in the case of the coefficient of GDP/capita, are pretty large. These statistical considerations lead to a weak relationship between Taxes on property and GDP/Capita within EU28.

Also, the Line Fit Plots shows the significant spread of European countries in relation to the indicators analyzed. It can be seen that the trend line is followed only by a relatively reduced number of countries, many of which are quite far from it. This proves the lack of homogeneity within the EU28 in terms of correlation between property taxes level and the living standards of citizens of European countries. There are countries in Europe Union with high level of development and reduced property taxes, while some countries with lower level of development have higher property taxes. According to the data analyzed, there are significant discrepancies within the EU28 in terms of the ratio between property taxation and the purchasing power. Thereby, is revealed the high necessity to create a more uniform property tax system within European Union, which takes into account the purchasing power of citizens. However, even the statistics of the regression are not very relevant because of this lack of homogeneity within the Eu28, it can be drawn some relevant conclusions referring to the positioning of EU countries by GDP/capita and level of taxes on property.

Thus, the positioning of the new European Union member states comparing to developed countries from the EU regarding the GDP/capita and the taxes on property is shown in Figure 1:

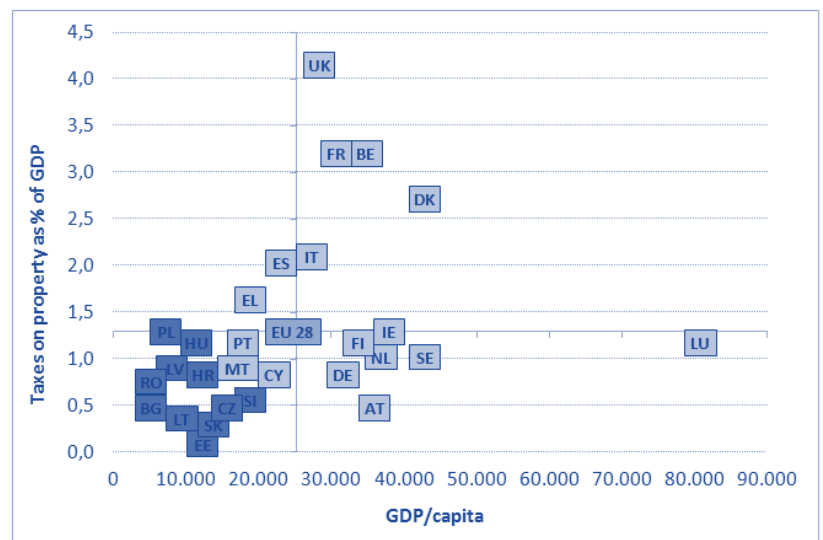

Figure 2: Grouping EU countries by GOP/capita and Taxes on property, source of data: Eurostat

It is easy to see that all eleven countries with economies in transition are in the bottom left of the chart grouping the European countries by GDP/capita and taxes on property. This shows that in these countries is a very low level of property taxation, correlated with low living standards. All these countries are below the European average both in terms of property taxation and in terms of GDP/capita.

The situation of developed countries from EU28 is not as homogeneous as that of the countries from Eastern Europe. They are grouped into several categories. The first category involves a level of GDP/capita above the average EU28. Among these countries, the first group includes countries with high property taxes (UK, France, Belgium and Denmark] and the second group includes countries with low levels of properties taxation (Ireland, Finland, Netherlands, Sweden, Germany, Austria and Luxembourg].

As an example of first group, in France a net wealth tax (ISF) is charged to resident individuals, the amount of assets held exclusively passive if the net value of these assets exceeds 790,000 Euros. Assets, equity, certain life insurance policies and other miscellaneous assets are excluded from this tax. An exemption of $75 \%$ is applied to some registered shares held by employees, managers or shareholders and a 50\% deduction from income 
tax applies to capital investments in SMEs. As an example of second group, in Germany the wealth tax is not applicable. The property tax is charged annually by all provinces, according to the tax assessed value of land and buildings located in their region. Basically, share transfers real property tax amounts to $3.5 \%$ and from 1 January 2007, the German Lander, can modify their own share and as a result, half of them increased their share. Inneritance and gift taxes were amended in 2008 and are charged at rates ranging from $7 \%$ to $50 \%$, depending on the value recorded.

The second category involves the countries with GDP/capita very close or below the average Eu28. Among these countries, the first group includes countries with relative high property taxes (Italy, Spain and Greece) and the second group includes countries with low levels of properties taxation (Portugal, Malta and Cyprus).

For a better discussion of the results, in the following table are presented the values of property taxes as percentages of GDP for the EU28 member states (year 2011):

\begin{tabular}{|c|c|c|c|c|c|}
\hline $\begin{array}{l}\text { 誩 } \\
\text { 訔 }\end{array}$ & 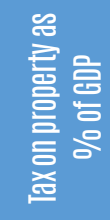 & $\begin{array}{l}\text { 謞 } \\
\text { 訔 }\end{array}$ & 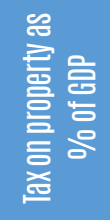 & $\begin{array}{l}\text { 흘 } \\
\text { 訔 }\end{array}$ & 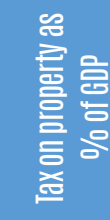 \\
\hline BE & 3.2 & ES & 2.0 & AT & 0.5 \\
\hline$B G$ & 0.6 & FR & 3.2 & PL & 1.2 \\
\hline $\mathrm{CZ}$ & 0.5 & II & 2.1 & PI & 1.1 \\
\hline HR & 0.7 & CY & 0.8 & RO & 0.8 \\
\hline DK & 2.7 & IV & 1.0 & SI & 0.6 \\
\hline $\mathrm{DE}$ & 0.9 & LI & 0.5 & SK & 0.4 \\
\hline $\mathrm{EE}$ & 0.3 & LU & 1.2 & $\mathrm{Fl}$ & 1.1 \\
\hline IE & 1.2 & HU & 1.1 & SE & 1.0 \\
\hline $\mathrm{El}$ & 1.6 & MT & 1.0 & UK & 4.2 \\
\hline EU28 & 1.3 & NL & 1.1 & & \\
\hline
\end{tabular}

Table 3: The values of property taxes as percentages of GDP within EU28, source of data: Eurostat
As can be seen in the Table 3, the highest Ievel of taxation of transitional countries is Poland with $1.2 \%$, followed by Hungary with $1.1 \%$. Note that these maximal values are still below the Eu28 average, which is $1.3 \%$. Also, these values are very far from the maximum European value which is the UK at level of 4.2\%. The lowest level of property taxation of transitional countries and represents the minimum of $\mathrm{EU}$ is Estonia with $0.3 \%$. Very close to this minimum of property taxation is Slovakia with $0.4 \%$ and Lithuania with $0.5 \%$. In the same quadrant with transitional countries are also positioned Portugal (1.1\%), Malta $[1.0 \%$ ) and Cyprus $[0.8 \%$ ], which have low values of taxes on property and are below the European average of GDP/capita.

On the other hand, great differences are recorded in the UK [4.2\%), Belgium [3.2\%], France [3.2\%] and Denmark [2.7\%) with very high levels of property taxation, correlated with above average GDP/capita. A special case to mention is the UK, with the maximum taxation of properties from entire EU28. In the UK, the stamp tax on land and property varies between $0 \%$ and $4 \%$, depending on the value of the transaction (with significant deductions as first purchaser]. Starting with 2012, a new rate of $7 \%$ applies to the purchase of residential properties over 2 million pounds.

Between these groups are positioned countries as Italy [2.1\%], Spain [2.0\%) and Greece (1.6\%) which are very close to Eu28 average in terms of GDP/capita and with higher level of taxation than EU28 average.

\section{Conclusion}

As was shown in the beginning of the paper, the present research aims to argue the use of property taxation as an instrument of fiscal policy, especially in the Eastern European countries. Property tax is probably one of the most unpopular tax instruments because it is hard to avoid, and in 
some countries requires considerable financial resources from owners. Furthermore, the limited revenue from property taxation in the most of European countries suggests that citizens do not agree increases in their property taxes and the governments know this.

As seen in the grouping of European countries in those four quadrants, the most of former communist countries undervalues the importance of this type of tax. Usually, in these countries, the reason of low property taxation is given by social criteria because of a large numbers of low income owners. At the same time, there are countries in EU28 such as the UK, Belgium, and France where the tax Ievel is very high. Also, can be seen from the grouping made, there is a wide variety of combinations of tax systems and the level of development in the Eu28. However, it is observed that scattering is higher in developed countries. Thereare both developed countries with a high level of property taxes and developed countries with low level of these taxes. Former communist countries are fitting all in the same group, which assumes lower taxes, with little differences.

As was shown during the paper, the experts [1, $3,4,7,10]$ continue to emphasize the benefits of property tax due to its high efficiency and relatively low cost. The negative impact of this tax on economic growth is very low, as it does not affect the directly productive sector or the consumption, as do most other types of taxes. In addition, it offers a high accuracy of taxation and the possibilities of fraud are very low. Property taxation is, therefore, currently considered to be underused in most countries, despite numerous arguments for it.

Efficiency of a tax is often measured in terms of its effectiveness and of economic distortions that may create by an excess of taxation. The tax can cause additional costs to the economy, which may delay the achievement of a medium and long- term growth. In this context, the main advantage of property taxes is that are seen by taxpayers as reasonable payments for local services which usually reflect the only the administrative costs of the local authorities. The efficiency and the equity of these taxes are strong reasons for finding the best ways to further enhance the role of property taxes, especially in terms of annual taxes on real estate.

Is it realistic to believe that will be registered an increasing of the share of property taxes of GDP in the next years for all developing countries in the $\mathrm{EU}$, but with a greater potential for growth in many developed countries which today rely only slightly on the taxation of real estate as Austria, Luxembourg or even Germany. Finally, it clearly results the necessity of a serious analysis at European Union level to assess the current capabilities of member states in order to take political decisions on the future role of property taxes in the growth of the European economy.

\section{References}

[1] Anghel, I. \& Sipos, C. [2012). Valuation for Property Tax Purposes: Analysis of the EU Transitional Countries, 2012 FIG Commission 7: International Seminar state Land Management in Iransitional Countries: Issues and Ways Forward, Budapest, Hungary,

[2] Arnold, J. [2008). Do Tax structures Affect Aggregate Economic Growth?: Empirical Evidence from a Panel of OECD Countries". OECD Economics Department Working Papers, No. 643, OECD Publishing

[3] Arnold, J.; Brys B.; Heady, C.; Johansson, A.; Schwellnus, C \& Vartia, L. [2011). Tax policy for economic recovery and growth. The Economic Journal, Vol. 121, Issue 550, pp. 59-80, D0|: 10.1111//.1468-0297.2010.02415.x

[4] Bahl, R.; Martinez-Vazquez, J. \& Youngman, J. [2010). Challenging the Conventional Wisdom on 
the Property Tax, ISBN 978-1-55844-200-9, Lincoln Institute of Land Policy

[5] Balázs, É. \& Dubravko, M. (2007). Determinants of House Prices in Central and Eastern Europe. Comparative Economic Studies. No. 49, pp. 367-388, D0l:10.1057/palgrave.ces.8100221

[6] Johansson, A.; Heady, C.; Arnold, J.; Brys, B.; \& Vartia, L. (2008). Tax and Economic Growth. OECD Economics Department Working Papers, №. 620, OECD Publishing, Dol 10.1787/241216205486

[7] Key, K.G. [2012). Property Tax Strategic Interaction: A Test of Tax Versus Yardstick Competition, in Toby stock (ed.) Advances in Taxation (Advances in Taxation, Volume 20), ISBN: 978-1-78052-592-1, Emerald Group Publishing Limited, pp. 181 - 201

[8] Millington, A.F. (2014). An Introduction to Property Valuation, Fifth Edition, Routlege - Taylor \& Francis, ISBN 978-0-7282-0350-1

[9] Muellbauer, J. [2005). Property Taxation and the Economy after the Barker Review. The Economic Journal, Vol. 115, Issue 502: pp. 99-117, Dol: 10.1111//.0013-0133.2005.00982.x

[10] Norregaard, J. [2013]. Taxing Immovable Property Revenue Potential and Implementation Challenges. IMF Working Paper, WP/13/129

[11] Rybkowska, A. \& Schneider, M. [2011]. Housing Conditions in Europe in 2009. Statistics in Focus, Eurostat, $4 / 2011$

[12] Tosun, M. S. \& Abizadeh, S. (2005). Economic growth and tax components: an analysis of tax changes in OECD. Applied Economics, Vol. 37, Issue 19, pp. 2251-2263

[13] European Commission (2013). "Taxation trends in the European Union" - 2013 Edition, Eurostat Statistical Books

[14] European Commission (2014). Eurostat, Available from:

http://ec. europa.eu/eurostat, Accessed: 2014-10 


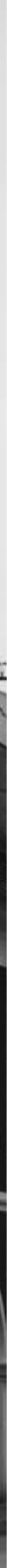

